\title{
ANALISIS OPINI AUDIT GOING CONCERN: PREDIKSI KEBANGKRUTAN, LEVERAGE DAN PERTUMBUHAN PERUSAHAAN PADA PERUSAHAAN PERBANKAN DAN PEMBIAYAAN YANG GO PUBLIC DI BEI
}

\author{
Enggar Nursasi \\ Evi Maria \\ STIE Malangkuçeçwara \\ Jl. Terusan Candi Kalasan, Jawa Timur 65142 \\ Email:enurs@stie-mce.ac.id
}

Abstract

The purpose of this study to prove whether banks and finance companies that go public on the Stock Exchange for the period 2009-2011 with the reception an unqualified opinion with an explanatory paragraph going concern enterprise, influenced by the prediction of bankruptcy, the low value of the company's leverage ratio, which means assets owned more slightly compared with corporate debt and falling growth. The data used are secondary data from financial reports issued by independent auditors. In this study, there are two variables is the dependent variable in the form of going concern audit opinion and independent variables such as bankruptcy prediction, leverage and growth companies. Sample criteria are banking and finance company that is consistently in IDX listings from 2009 to 2011, which contained the independent auditor's report on the financial statements of the company respectively. Data analysis was performed using a hypothesis test with Partial Least Square $(P L S)$ by reason of the samples in this study was very small $(N=15)$, the data are not normally distributed and independent variables (going concern opinion) has a nominal size scale. The analysis shows that significant bankruptcy prediction variables, the variable Leverage and Growth Company insignificant. With these results it can be said that the hypothesis is accepted ie Bankruptcy 
Prediction affect the provision of Going Concern Audit Opinion. Hypothesis 2 and 3 are not accepted, the Company's Leverage and Growth does not affect the provision of Going Concern Audit Opinion .

Keywords: going concern audit opinion, prediction of bankruptcy, leverage and company growth

Perusahaan bergerak dalam bidang apapun dalam beroperasi perlu menjaga keprofesionalannya untuk mendapatkan kepercayaan dari masyarakat. Dengan kepercayaan yang kuat dari masyarakat tentunya perusahaan akan lebih dapat bertahan dalam menghadapi persaingan bisnis yang semakin ketat. Seperti halnya perbankan dan pembiayaan lainnya merupakan perusahaan yang semakin lama semakin menjamur dalam menyediakan jasa keuangan bagi seluruh lapisan masyarakat. Salah satu unsur untuk menguatkan kepercayaan masyarakat pada suatu perusahaan adalah dipublikasikannya laporan keuangan yang telah diaudit. Auditor dalam mengeluarkan opini atas laporan keuangan perusahaan harus benar- benar memperhatikan kondisi keuangan perusahaan. Sebelum opini audit wajar tanpa pengecualian dikeluarkan, auditor bisa menambah paragraf penjelasan berupa keberlanjutan usaha perusahaan yang dapat dinyatakan dengan istilah going concern perusahaan tersebut.

Opini yang dilengkapi dengan penjelasan tentang kelangsungan hidup going concern, akan menguatkan para investor dalam menentukan keputusan untuk menanamkan modalnya terhadap suatu perusahaan. Para pemakai laporan keuangan merasa bahwa pengeluaran opini going concern ini dapat juga digunakan sebagai prediksi kebangkrutan suatu perusahaan. Menurut MC Keown, et al., 1991 (dalam Fanny dan Saputra, 2005) menyatakan bahwa studi di Amerika Serikat menemukan hampir mendekati $50 \%$ perusahaan tidak menerima kualifikasi going concern sebelum mereka bangkrut. Semakin kondisi perusahaan terganggu atau memburuk maka akan semakin besar kemungkinan perusahaan menerima opini audit going concern. Sebaliknya pada perusahaan yang tidak pernah mengalami kesulitan keuangan, auditor tidak pernah mengeluarkan opini audit going concern.

Sebenarnya auditor tidak bertanggungjawab terhadap kelangsungan hidup perusahaan, tetapi dalam melakukan audit, seharusnya kelangsungan hidup perusahaan perlu menjadi pertimbangan auditor dalam memberikan opininya sehingga menambah keyakinan para pengguna laporan keuangan (Rahayu \& Pratiwi, 2011). Auditor dapat mengidentifikasi kondisi suatu perusahaan mengenai kelangsungan hidup perusahaan melalui kondisi sebagai berikut: 1) Tren negatif: kerugian operasi, kekurangan modal kerja, aliran kas negatif dari aktivitas operasi, dan rasio keuangan yang jelek; 2) Petunjuk lain tentang kemungkinan kesulitan keuangan: gagal memenuhi kewajiban, pengunggakan pembayaran deviden, penolakan oleh pemasok terhadap pengajuan pembelian kredit, restrukturisasi utang, mencari sumber pendanaan baru 
atau menjual sebagian besar asset; 3) Masalah intern perusahaan: pemogokan kerja, ketergantungan besar atas kesuksesan proyek tertentu, komitmen jangka panjang yang bersifat tidak ekonomis; 4) Masalah luar perusahaan: pengaduan gugatan pengadilan, kehilangan franchise, lisensi atau paten lain, kehilangan pelanggan atau pemasok utama, kerugian akibat bencana yang tidak disuransikan. (IAPI 2001, seksi 341).

Ketika kondisi ekonomi terjadi kondisi ketidakpastian, para investor sangat berharap para auditor memberikan early warning tentang kondisi kegagalan keuangan perusahaan (Chen dan Church,1996 dalam Warnida, 2011). Auditor juga bertanggungjawab untuk menilai apakah terdapat kesangsian besar terhadap kemampuan perusahaan dalam mempertahankan kelangsungan hidupnya (going concern) dalam periode satu tahun sejak tanggal laporan audit (SPAP seksi 341, 2001).

Paragraf penjelasan dalam opini audit sangat membantu para pengguna laporan keuangan tentang kondisi perusahaan. Terutama yang berkaitan dengan penjelasan auditor tentang pertimbangan going concern perusahaan yang tercermin dari prediksi kebangkrutan, tingkat penggunaan hutang (leverage) dan pertumbuhan perusahaan. sehingga rumusan masalah dalam penelitian ini adalah: Apakah pemberian opini going concern dipengaruhi oleh prediksi kebangkrutan; Apakah pemberian opini going concern dipengaruhi oleh leverage; Apakah pemberian opini going concern dipengaruhi oleh pertumbuhan perusahaan. Sehingga tujuan dari penelitian ini adalah untuk membuktikan apakah perusahaan perbankan dan pembiayaan yang go publik di BEI untuk periode 2009-2011 dengan penerimaan opini wajar tanpa pengecualian dengan paragraf penjelasan going concern perusahaan, dipengaruhi oleh prediksi kebangkrutan, rendahnya nilai perusahaan dan rasio leverage perusahaan yang berarti aktiva yang dimiliki lebih sedikit dibanding dengan hutang perusahaan dan turunnya pertumbuhan perusahaan.

\section{Opini Audit}

Evaluasi mengenai going concern perusahaan merupakan pekerjaan krusial bagi seorang auditor. Auditor harus menilai kemampuan perusahaan untuk bertahan hidup melalui investigasi yang komprehensif tentang kejadian-kejadian dan kondisikondisi yang berpengaruh terhadap kelangsungan hidup perusahaan tersebut. Auditor akan berhadapan dengan bukti-bukti yang kompleks dan mungkin saling bertentangan antara satu dengan yang lainnya. Auditor mengumpulkan bukti dalam waktu yang berbeda dan mengintegrasikan informasi dari bukti baru tersebut untuk membuat suatu pertimbangan (judgment). Pertimbangan audit terkonsentrasi pada asersi laporan keuangan tertentu, yaitu mulai dari keyakinan awal atas asersi tersebut hingga proses perbaikan setelah menerima dan menilai bukti audit yang baru. Pada proses pertimbangan audit, hasil prosedur yang dilaksanakan dalam perencanaan, 
pengumpulan bukti audit untuk berbagai tujuan audit, dan penyelesaian auditnya, dipertimbangkan karena mungkin diperlukan untuk memperoleh informasi tambahan mengenai kondisi dan peristiwa beserta bukti-bukti yang mendukung informasi tersebut.

Standar Profesional Akuntan Publik (SPAP) mengindikasikan bahwa apabila auditor mendapatkan bukti audit mengenai suatu pengujian selama masa interim, auditor harus menentukan bukti audit tambahan apa yang harus diperoleh untuk masa tersisa. Dalam melakukan penugasan umum, auditor ditugasi memberikan opini atas laporan keuangan perusahaan. Pendapat atau opini audit merupakan bagian yang tidak terpisahkan dari laporan audit. Dengan demikian auditor harus memberikan opini sudah didasarkan pada keyakinan profesonalnya. Auditor akan mengeluarkan kualifikasi laporan audit jika dalam menjalankan auditnya gagal mengkonfirmasi kepatuhan klien terhadap peraturan yang berlaku.

Menurut Standar Profesional Akuntan Publik (PSA29), jenis - jenis opini audit sebagai berikut:

- $\quad$ Pendapat wajar tanpa pengecualian (Unqualified Opinion)

Jika auditor telah melaksanakan pemeriksaan sesuai dengan standar auditing yang ditentukan oleh Ikatan Akuntan Indonesia, yaitu standar profesional akuntan publik, dan telah mnegumpulkan bahan-bahan pembuktian yang cukup untuk mendukung opininya, serta tidak menemukan adanya kesalahan material atau penyimpangan dari prinsip akutansi yang berlaku umum, maka auditor dapat memberikan pendapat wajar tanpa pengecualian.

- Pendapat wajar tanpa pengecualian dengan bahasa penjelasan yang ditambahkan (Unqualified Opinion with Explanatory Language)

Pendapat ini diberikan jika terdapat keadaan tertentu yang mengharuskan auditor menambahkan paragraf penjelasan dalam laporan audit, meskipun tidak mempengaruhi pendapat wajar tanpa pengecualian, seperti pendapat auditor sebagian didasarkan atas laporan auditor independen lain, terdapat keraguan yang besar tentang kemampuan suatu usaha dalam kelangsungan hidupnya, informasi lain dalam suatu dokumen yang berisi laporan keuangan auditan secara material tidak konsisten dengan informasi yang disajikan dalam laporan keuangan, dan sebagainya.

- Pendapat wajar dengan pengecualian (Qualified Opinion)

Pendapat wajar dengan pengecualian menyatakan bahwa laporan keuangan menyajikan secara wajar, dalam semua hal yang material, posisi keuangan, hasil usaha, dan arus kas sesuai dengan prinsip akuntansi yang berlaku umum, kecuali untuk dampak hal yang berkaitan dengan yang dikecualikan. Pendapat ini dinyatakan bilamana tidak adanya bukti kompeten yang cukup atau adanya pembatasan terhadap lingkup audit yang mengakibatkan auditor berkesimpulan bahwa ia tidak dapat menyatakan pendapat wajar tanpa pengecualian dan ia berkesimpulan tidak menyatakan tidak memberikan pendapat serta keyakinan 
auditor atas auditnya, bahwa laporan keuangan berisi penyimpangan dari prinsip akuntansi yang berlaku umum, yang berdampak material, dan ia berkesimpulan untuk tidak menyatakan pendapat tidak wajar.

- Pendapat tidak wajar (Adverse Opinion)

Suatu pendapat tidak wajar menyatakan bahwa laporan keuangan tidak menyajikan secara wajar posisi keuangan, hasil usaha, dan arus kas sesuai dengan prinsip akuntansi yang berlaku umum. Pendapat ini dinyatakan bila menurut pertimbangan auditor, laporan keuangan secara keseluruhan tidak disajikan secara wajar sesuai dengan prinsip akuntansi yang berlaku umum.

- Pernyataan tidak memberikan pendapat (Disclaimer of Opinion)

Dalam pernyataan tidak memberikan pendapat, auditor tidak menyatakan pendapat atas laporan keuangan. Pernyataan tidak memberikan pendapat ini cocok diberikan jika auditor, karena adanya pembatasan lingkup auditnya, tidak dapat melaksanakan audit yang cukup untuk memungkinkannya memberikan pendapat tidak boleh dinyatakan oleh auditor jika ia yakin berdasarkan auditnya, terdapat penyimpangan material dari prinsip akuntansi yang berlaku umum.

\section{Going Concern}

Going Concern merupakan kelangsungan hidup suatu badan usaha. Dengan adanya going concern, maka suatu entitas dianggap akan mampu mempertahankan kegiatan usahanya dalam jangka panjang. Laporan audit dengan modifikasi mengenai going concern merupakan suatu indikasi bahwa dalam penilaian auditor terdapat resiko auditee tidak dapat bertahan dalam bisnis. Dari sudut pandang auditor, keputusan itu melibatkan beberapa tahap analisis. Auditor harus mempertimbangkan hasil dari operasi, kondisi ekonomi yang mempengaruhi perusahaan, kemampuan membayar hutang dan kebutuhan likuiditas di masa yang akan datang.

Going concern dipakai sebagai asumsi dalam pelaporan keuangan sepanjang tidak terbukti adanya informasi yang menunjukan hal yang berlawanan (Contrary Information). Biasanya informasi yang secara signifikan dianggap berlawanan dengan ketidakmampuan satuan usaha dalam memenuhi kewajiban pada saat jatuh tempo tanpa melakukan penjualan sebagian besar aktiva kepada pihak luar melalui bisnis biasa, restrukturisasi hutang, perbaikan operasi yang dipaksakan dari luar dan kegiatan serupa yang lain (PSA no 30).

\section{Opini Audit Going Concern}

Opini audit going concern merupakan opini yang dikeluarkan auditor untuk memastikan bahwa apakah perusahaan dapat mempertahankan kelangsungan hidupnya (SPAP, 2001). Para pemakai laporan keuangan merasa bahwa pengeluaran opini audit going concern ini sebagai prediksi kebangkrutan suatu perusahaan. Pengeluaran opini audit going concern ini sangat berguna bagi para pemakai laporan 
keuangan untuk membuat keputusan yang tepat dalam berinvestasi. Investor perlu untuk mengetahui kondisi keuangan perusahaan, terutama yang menyangkut kelangsungan hidup perusahaan tersebut. Hal ini membuat auditor mempunyai tanggung jawab yang besar untuk mengeluarkan opini audit going concern yang konsisten dengan keadaan sesungguhnya.

Kewajiban auditor mengungkapkan dampak kondisi ekonomi terhadap kemampuan entitas untuk mempertahankan kelangsungan hidupnya. Arens (dalam Fanny dan Saputra 2005) menyatakan beberapa faktor yang dapat menimbulkan ketidakpastian mengenai kelangsungan hidup perusahaan adalah:

- Kerugian usaha yang besar secara berulang atau kekurangan modal kerja.

- Ketidakmampuan perusahaan untuk membayar kewajibannya pada saat jatuh tempo dalam jangka pendek.

- Kehilangan pelanggan utama, terjadinya bencana yang tidak diasuransikan seperti gempa bumi atau banjir atau masalah perburuhan yang tidak biasa.

- Perkara pengadilan, gugatan hukum atau masalah serupa yang sudah terjadi yang dapat membahayakan kemampuan perusahaan untuk beroperasi.

Seorang auditor ketika memeriksa kondisi keuangan suatu perusahaan dalam audit tahunan, auditor harus menyediakan laporan audit untuk digabungkan dengan laporan keuangan perusahaan. Salah satu hal penting yang harus diputuskan adalah apakah perusahaan dapat mempertahankan hidupnya (going concern). Audit report dengan modifikasi mengenai going concern, mengindikasikan bahwa dalam penilaian auditor terdapat resiko perusahaan tidak dapat bertahan dalam bisnis. Di lain pihak, perusahaan yang "sehat" memperoleh opini "standar" atau unqualified. Dari sudut pandang auditor, keputusan tersebut melibatkan beberapa tahap analisis.

Mengacu pada Statement On Auditing Standar No 59 (AICPA, 1988), auditor harus memutuskan apakah perusahaan klien akan bisa bertahan di masa yang akan datang. Selain itu IAI juga menyiapkan Interpretasi Pernyataan Standar Auditing (IPSA) Nomor 30 melalui komite Standar Profesional Akuntan Publik tentang "Laporan Auditor Independen tentang Dampak Memburuknya Ekonomi Indonesia terhadap Kelagsungan Hidup Entitas". IPSA menganggap auditor perlu mempertimbangkan 3 hal sebagai berikut:

- Kewajiban auditor untuk memberikan saran bagi kliennya dalam mengungkapkan dampak kondisi ekonomi tersebut (jika ada) terhadap kemampuan entitas untuk mempertahankan kelangsungan hidupnya.

- Pengungkapan peristiwa kemudian yang mungkin timbul sebagai akibat kondis ekonomi tersebut.

- Modifikasi laporan audit bentuk baku jika memburuknya kondisi ekonomi tersebut berdampak terhadap kemampuan entitas untuk mempertahankan kelangsungan hidupnya. 
PSA Nomor 30 memberikan pedoman kepada auditor tentang dampak kemampuan satuan usaha dalam mempertahankan kelangsungan hidupnya terhadap opini auditor sebagai berikut:

- Jika auditor yakin bahwa terdapat kesangsian mengenai kemampuan satuan uasaha dalam mempertahankan kelangsungan hidupnya dalam waktu pantas, ia harus: a) memperoleh informasi mengenai rencana manajemen yang ditujukan untuk mengurangi dampak kondisi dan peristiwa tersebut; b) menetapkan kemungkinan rencana tersebut secara efektif dilaksanakan.

- Jika manajemen tidak memiliki rencana yang mengurangi dampak kondisi dan peristiwa terhadap kemampuan satuan usaha dalam mempertahan kelangsungan hidupnya auditor mempertimbangkan untuk memberikan pernyataan tidak memberikan pendapat (disclaimer).

- Jika menajemen memiliki rencana tersebut, lagkah selanjutnya yang dilakukan oleh auditor adalah menyimpulkan (berdasarkan pertimbangannya) atas efektifitas rencana tersebut.

\section{Opini Audit dan Model Kebangkrutan}

Salah satu hal terpenting yang harus diputuskan oleh auditor adalah apakah perusahaan dapat mempertahakan kelangsungan hidupnya (going concern). Laporan keuangan dengan modifikasi tentang going concern mengindikasikan bahwa dalam penilaian auditor ada resiko bahwa perusahaan tidak dapat bertahan dalam bisnisnya. (Lenard, et al., 1998). Mckown, et al. (1991) meneliti opini audit dari perusahaan yang akan segera bangkrut, dan hasilnya menunjukkan bahwa perusahaan yang akan segera bangkrut ternyata menerima opini tanpa modifikasi dan perusahaan ini lebih sedikit kemungkinannya untuk mempunyai indikasi-indikasi akan kesulitan keuangan, serta memiliki periode waktu yang pendek antara akhir tahun fiskal dengan tanggal laporan audit. Auditor ada kemungkinan gagal untuk memberikan pendapat tentang adanya indikasi kebangkrutan yang ternyata perusahaan mengalami kebangkrutan dalam beberapa tahun kemudian, yang disebabkan karena perusahaan pada posisi ambang batas antara kebangkrutan dengan kelangsungan usahanya.

Peneliti lain Mutchler (1985) meneliti perusahaan dengan katagori bermasalah dengan ciri arus kas negatif, pendapatan operasi negatif, modal kerja negatif, kerugian pada tahun berjalan atau defisit saldo laba tahun berjalan. Model prediksi kebangkrutan yang digunakan adalah model Altman (1968) yang menemukan bahwa perusahaan dengan probabilitas serta solvabilitas yang rendah sangat berpotensi mengalami kebangkrutan yang dikenal dengan Z Score Model. Altman dan Mcgough (1974) menemukan bahwa tingkat prediksi kebangkrutan dengan menggunakan suatu model prediksi mencapai tingkat keakuratan $82 \%$, sedangkan dengan menggunakan opini audit tingkat keakuratannya hanya mencapai $46 \%$. Seperti hasil 
penelitian Fanny dan Saputra (2005) yang menyatakan bahwa hubungan antara model prediksi kebangkrutan memberikan hasil yang signifikan, terutama untuk proksi Z Score. Hasil ini menunjukkan bahwa penggunaa model prediksi kebangkrutan yang dikembangkan oleh Altman mempengaruhi ketepatan pemberian opini audit. Hasil ini juga konsisten dengan penelitian terdahulu yaitu McKeown, et al. (1991) dan Mutchler (1985) di mana hasilnya menunjukkan bahwa opini audit going concern lebih banyak diberikan kepada klien yang nilai Z Score yang rendah.

Sehingga hipotesis dalam penelitian ini:

H1 : pemberian opini audit going concern dipengaruhi oleh prediksi kebangkrutan.

\section{Opini Audit dan Leverage}

Rasio Leverage menunjukkan gambaran tingkat penggunaan hutang sebagai sumber pembiayaan perusahaan. Jika jumlah aktiva yang dimiliki perusahaan lebih sedikit dibandingkan dengan jumlah hutang perusahaan tersebut, mengindikasikan bahwa dalam operasional perusahaan lebih banyak dibiayai dengan hutang. Keadaan inilah yang memungkinkan perusahaan menerima opini audit ging concern. Perusahaan dengan nilai aset lebih kecil daripada kewajibannya akan menghadapi bahaya kebangkrutan (Susanto, 2009) yang mendukung hasil penelitian terdahulu (Chen \& Church, 1992) yang mengkaji variabel kegagalan pembayaran utang untuk menjelaskan opini audit, juga hasil penelitian Rudyawan dan Badera (2009) yang menyatakan bahwa semakin tinggi utang perusahaan terhadap kemampuan perusahaan dalam membayarnya, semakin buruk kinerja perusahaan dan menimbulkan ketidakpastian kelangsungan hidup perusahaan sehingga berpeluang untuk mendapatkan opini audit going concern.

Sedangkan hasil penelitian Potrenola (2004) menyatakan sebaliknya yaitu debt to equity perusahaan kurang dipertimbangkan oleh auditor dalam memberikan opini audit atas laporan keuangan perusahaan yag diaudit. Hal senada juga dari hasil penelitian Rahayu dan Pratiwi (2011) membuktikan bahwa rasio leverage tidak berpengaruh terhadap penerimaan opini audit going concern dengan nilai probabilitas (sig) 0.628. Menurut Robert Ang (1997) dalam penelitian Siregar dan Rahman (2011) menyatakan debt to equity ratio menunjukkan komposisi total utang terhadap total ekuitas. Semakin tinggi debt to equity ratio menunjukkan komposisi total utang semakin besar dibanding dengan total modal sendiri, sehingga berdampak semakin besar beban perusahaan terhadap pihak luar (kreditur).

Sehingga hipotesis dalam penelitian ini:

$\mathrm{H} 2$ : pemberian opini audit going concern dipengaruhi oleh leverage

\section{Opini Audit dan Pertumbuhan Perusahaan}

Pertumbuhan perusahaan dapat dilihat dari pertumbuhan aset perusahaan. Dengan semakin meningkatnya aset perusahaan akan menunjukkan bahwa perusahaan 
mempunyai kekuatan untuk berkembang dan mengindikasikan kemampuan perusahaan dapat mempertahanka kelangsungan hidupnya. Perusahaan yang memiliki pertumbuhan yang signifikan kemungkinan besar tidak mendapatkan opini audit going concern (Rahayu dan Pratiwi, 2011). Hasil penelitian Fanny dan Saputra (2005) menunjukkan bahwa pertumbuha perusahaan tidak berpengaruh terhadap pemberian opini audit.

Hal ini terjadi karena pertumbuhan aset perusahaan tidak diikuti dengan kemampuan perusahaan untuk menghasilkan laba serta meningkatkan saldo labanya, sehingga dari survey yang dilakukan terhadap 93 perusahaan manufaktur bayak ditemukan perusahaan yang walaupun memiliki total aset yag meningkat setiap tahunnya namun tetap saja mengalami rugi ataupun memiliki saldo laba yang negatif. Hal ini senada dengan hasil penelitian Rahayu dan Pratiwi (2011) yang membuktikan bahwa pertumbuhan perusahaan tidak berpengaruh terhadap penerimaan opini audit going concern dengan nilai probabilitas (sig) 0.735 .

Sehingga hipotesis dalam penelitian ini:

H3 : pemberian opini audit going concern dipengaruhi oleh pertumbuhan perusahaan.

\section{METODE}

Populasi penelitian adalah perusahaan perbankan dan pembiayaan yang go publik di BEI untuk tahun 2009 sampai 2011. Dengan metode purposive sampling, sampel penelitian yaitu untuk perusahaan yang memenuhi kriteria sebagai berikut: 1) perusahaan perbankan dan pembiayaan untuk periode 2009-2011 minimal 1 kali mengalami laba bersih yang negatif, 2) menerbitkan secara berturut-turut laporan keuangan yang diaudit untuk periode 2009-2011 dengan periode laporan 1 Januari sampai 31 Desember. Data dikumpulkan dengan cara observasi, yaitu mengambil dari laporan keuangan yang sudah dipublikasikan oleh perusahaan di BEI.

Analisis data dilakukan uji hipotesis dengan menggunakan analisa Partial Least Square (PLS), dengan alasan:

- Sampel penelitian sangat sedikit $(\mathrm{N}=15)$

- Data tidak berdistribusi normal

- Variabel independen (Opini Audit Going Concern) mempunyai skala ukuran nominal.

Partial Least Square (PLS) dapat digunakan untuk mengkonfirmasi teori maupun digunakan untuk menjelaskan ada atau tidaknya hubungan antara variabel laten.

Menurut Ghozali (2008), model PLS melakukan estimasi parameter yang dikatagorikan sebagai berikut:

- Weight estimate yang digunakan untuk menciptakan skor variabel laten.

- Path estimate yang menghubungkan variabel laten dan antar variabel laten, serta indikatornya (loading). 
- Means dan lokasi parameter (nilai konstanta regresi) untuk indikator dan variabel laten

- Selain itu model jalur semua variabel laten dalam PLS terdiri dari tiga set hubungan:

- Inner model yang menspesifikasi hubungan antar variabel laten (inner relation, structural model dan substantive theory).

- Outer model yang menspesifikasi hubungan antar variabel laten dengan indikator atau variabel manifest-nya (outer relation, measurement model).

- Weight relation agar variabel laten bias diestimasi, dengan asumsi bahwa variabel laten dan variabel manifest diskala zero means dan unit variansi sama dengan satu, sehingga parameter konstanta dapat dihilangkan dalam modal.

Adapun langkah-langkah pengujian model empiris penelitian dengan Partial Least Square, sebagai berikut:

- Spesialisasi model, analisis jalur hubungan antar variabel terdiri dari:

- Outer model, yaitu spesifikasi hubungan antara variabel laten dengan indikatornya, mendefinisikan karakter konstruk dengan variabel manifest-nya.

- Inner model, yaitu spesifikas hubungan antara variabel laten, menggambarkan hubungan antar variabel laten berdasarkan teori substantive penelitian.

- Weight relation, estimasi nilai kasus variabel laten, inner dan outer model memberika spesifikasi yng diikuti dalam estimas alogaritma PLS. Analisis full model mencakup 2 hal: 1) Outer model, digunakan untuk menguji validitas dan realibilitas antar indikator dengan konstruk; 2) inner model, digunakan untuk menguji hubungan antar variabel laten (uji hipotesis).

- $\quad$ Analisis Outer Model

Digunakan untuk menguji validitas dan realibilitas dari daftar pertanyaan yang digunakan.

- $\quad$ Analisis Inner Model

Digunakan untuk menguji hubungan antar variabel laten (uji hipotesis), yaitu antar konstruk:

- Prediksi Kebangkrutan terhadap Opini Audit Going Concern

- $\quad$ Leverage terhadap Opini Audit Going Concern

- Pertumbuhan Perusahaan terhadap Opini Audit Going Concern

Pengujian dengan melihat nilai nilai $P$ value untuk melihat signifikansi (alpha $5 \%$ ), jika nilai $P$ value lebih kecil dari 5\% maka hipotesis (H1) diterima dan $\mathrm{H} 0$ ditolak, dan sebaliknya. Atau dengan melihat nilai $t$, jika $t_{\text {hitung }}$ lebih besar dibanding dengan $\mathrm{t}_{\text {tabel }}$ (alpha 5\%), maka hipotesis (H1) diterima dan H0 ditolak, dan sebaliknya. 
Sedangkan koefisien determinasi digunakan untuk melihat seberapa besar pengaruh variabel eksogen terhadap endogen, semakin besar nilainya berarti semakin besar pengaruhnya.

\section{HASIL DAN PEMBAHASAN}

Penelitian dilakukan untuk mengetahui apakah Opini Audit Going Concern dipengaruhi oleh Prediksi Kebangkrutan, Leverage dan Pertumbuhan Perusahaan. Penelitian dilakukan pada perusahaan Perbankan dan Pembiayaan yang go public di BEI pada tahun 2009 sampai 2011. Dengan ketentuan sampel untuk penelitian ini yaitu: 1) perusahaan perbankan dan pembiayaan untuk periode 2009-2011 minimal 1 kali mengalami laba bersih yang negatif, 2) menerbitkan secara berturut-turut laporan keuangan yang diaudit untuk periode 2009-2011 dengan periode laporan 1 Januari sampai 31 Desember. Hasil observasi peneliti memperoleh sampel sebanyak 15 , sehingga hal ini membuat peneliti merubah metode analisis dari regresi logistik ke Partial Least Square (PLS). Dengan mengacu pada keunggulan PLS yaitu data tidak harus berdistribusi normal multivariate (indikator dengan skala katagori ordinal, interval sampai rasio dapat digunakan pada model yang sama) dan ukuran sampel tidak harus besar.

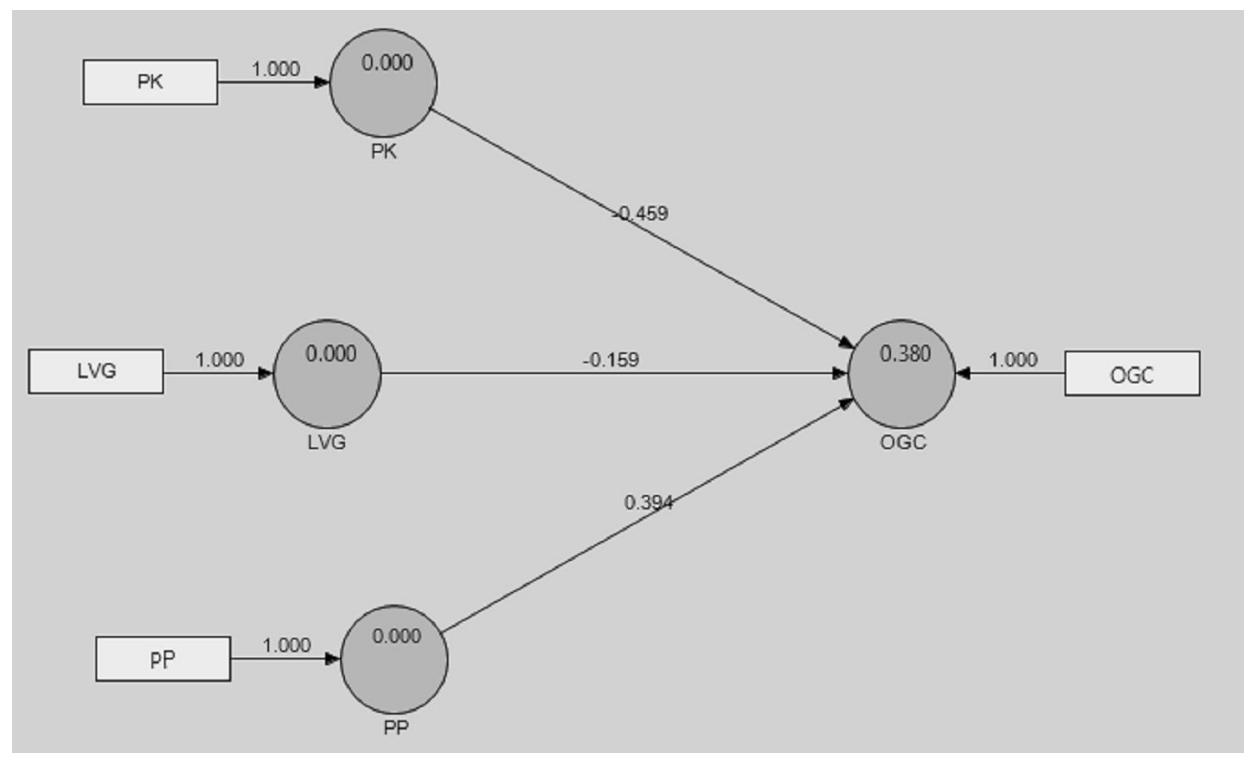

Gambar 1. Koefisien Determinasi 


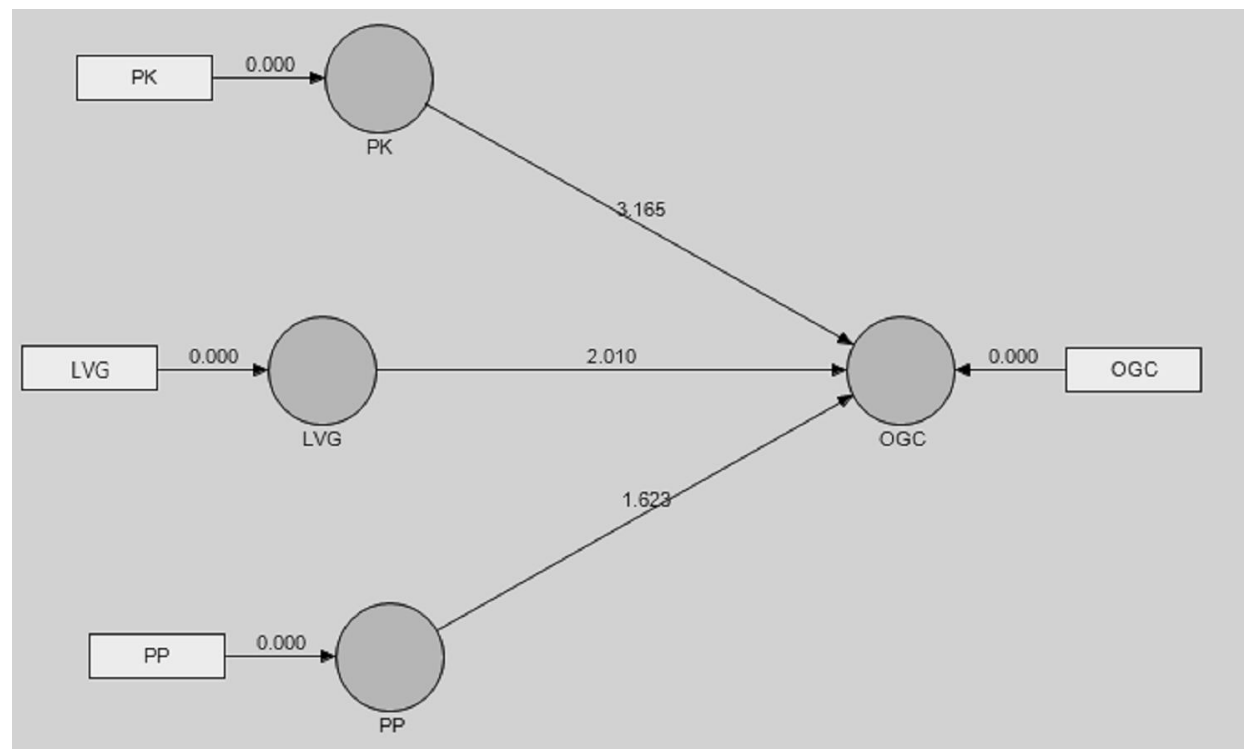

Gambar 2. Uji Signifikansi T- Value

Tabel 1. Path Coeficients (Mean, STDEV, T-Values)

\begin{tabular}{lcccccr}
\hline & $\begin{array}{c}\text { Original } \\
\text { Sample } \\
(\boldsymbol{O})\end{array}$ & $\begin{array}{c}\text { Sample } \\
\text { Mean }(\boldsymbol{M})\end{array}$ & $\begin{array}{c}\text { Standand } \\
\text { Deviation } \\
(\text { STDEV })\end{array}$ & $\begin{array}{c}\text { Standard } \\
\text { Error } \\
(\text { STERR })\end{array}$ & $\begin{array}{c}\text { T Statistics } \\
(\mid \boldsymbol{O} / \text { STERR } \mid)\end{array}$ & P value \\
\hline PK -> OGC & -0.458579 & -0.481012 & 0.144905 & 0.144905 & 3.164686 & $0.009003^{* *}$ \\
LVG -> OGC & -0.159497 & -0.164893 & 0.079338 & 0.079338 & 2.010345 & $0.069559^{*}$ \\
PP -> OGC & 0.393581 & 0.35913 & 0.242513 & 0.242513 & 1.622925 & 0.13289 \\
\hline
\end{tabular}

* : signifikan pada alpha $10 \%$

$* *$ : signifikan pada apha $5 \%$

\section{Keterangan:}

PK : Prediksi Kebangkrutan

LVG : Leverage

PP : PERTUMBUHAN PERUSAHAAN

OGC : Opini Audit Going Concern

\section{Pengujian Hipotesis 1}

Analisis pengaruh prediksi kebangkrutan terhadap opini audit going concern (Hipotesis 1). Dari table 1 di atas dapat dilihat hasil pengujian diperoleh nilai Tstatistic sebesar 3.164686. Nilai tersebut lebih besar dari $t_{\text {tabel }} 2.2009$, selain itu dapat dilihat $P$ value sebesar 0.009003 dengan alpha 5\%, berarti secara signifikan pemberian opini audit going concern dipengaruhi oleh prediksi kebangkrutan. Hasil 
ini mendukung penelitian sebelumnya yang dilakukan oleh Fanny, Margaretta dan Saputra (2005) yang menyatakan bahwa penggunaan model prediksi kebangkrutan yang dikembangkan oleh Altman (Z Score) mempengaruhi ketepatan pemberian opini audit.

Penerimaan hipotesis pertama ini juga mendukung penelitian yang dilakukan oleh Sharma dan Sidhu (2001), Mutchler (1985), Dupoch, et al. (1987), Peel (1989), Mckeown, et al. (1991), dan Citron dan Taffler (1992), di mana hasilnya menunjukkan opini audit going concern lebih banyak diberikan kepada klien yang memiliki nilai $Z$ Score yang rendah. Hasil penelitian ini juga konsisten dengan penelitian yang dilakukan oleh Hopwood, et al. (1994), Koh (1991), Levitan dan Knoblett (1985) dan Deakin (1977) yang menyarankan pada para auditor untuk menggunakan model-model prediksi kebangkrutan dalam membuat keputusan mengenai kelangsungan hidup perusahaan klien.

\section{Pengujian Hipotesis 2}

Analisis pengaruh leverage terhadap opini audit going concern (Hipotesis 2).

Dari table 1 di atas dapat dilihat hasil pengujian diperoleh nilai T-statistic sebesar 2.010345. Nilai tersebut lebih kecil dari tabel 2.2009 , selain itu dapat dilihat $P$ value sebesar 0.069559 dengan alpha $5 \%$, berarti tidak signifikan yang artinya dalam pemberian opini audit going concern, auditor tidak dipengaruhi oleh leverage. Leverage dalam penelitian ini menggunakan debt to equity ratio. Yang menggambarkan sejauhmana hutang dapat ditutupi oleh modalnya.

Hasil ini menunjukkan bahwa dalam memutuskan pemberian opini audit going concern auditor tidak dipengaruhi besarnya rasio hutang dibandingkan dengan modal yang dimiliki perusahaan saja, tetapi juga mempertimbangkan rasio lain seperti rasio aktivitas, likuiditas, solvabilitas dan lainnya. Hasil ini mendukung penelitian sebelumnya yang dilakukan oleh Fanny, Margaretta dan Saputra (2005), Rahayu, Ayu Wilujeng dan Pratiwi (2011), Arry (2007) dan Indira dan Ella (2008) yang membuktikan secara empiris bahwa rasio leverage tidak berpengaruh terhadap pemberian opini audit going concern.

\section{Pengujian Hipotesis 3}

Analisis pengaruh pertumbuhan perusahaan terhadap opini audit going concern (Hipotesis 3).

Dari table 1 di atas dapat dilihat hasil pengujian diperoleh nilai T-statistic sebesar 1.622925. Nilai tersebut lebih kecil dari t tabel 2.2009 , selain itu dapat dilihat $P$ value sebesar 0.13289 dengan alpha $10 \%$, berarti tidak signifikan yang artinya dalam pemberian opini audit going concern, auditor tidak dipengaruhi oleh pertumbuhan perusahaan. Pertumbuhan perusahaan dalam penelitian ini diproksikan dengan rasio pertumbuhan penjualan. 
Hasil menunjukkan bahwa meskipun perusahaan mengalami pertumbuhan penjualan tidak menjamin perusahaan yang bersangkutan akan mengalami peningkatan laba. Hasil penelitian ini mendukung hasil penelitian yang dilakukan oleh Fanny dan Saputra (2005), Eko dan Indira (2006), Arry (2007) serta Indira dan Ella (2008), yang membuktikan bahwa rasio pertumbuhan perusahaan tidak berpengaruh terhadap kemungkinan penerimaan opini audit going concern.

\section{KESIMPULAN DAN SARAN}

\section{Kesimpulan}

Berdasarkan analisis data dengan Partial Least Square dan pembahasan, maka dalam penelitian ini dapat disimpulkan bahwa prediksi kebangkrutan berpengaruh positif terhadap pemberian opini audit going concern. Sedangkan leverage dan pertumbuhan perusahaan berdasarkan hasil analisa memberikan pengaruh yang negatif terhadap pemberian opini audit going concern.

Hal ini dapat dijelaskan bahwa besarnya rasio hutang dibanding dengan modal yang dimiliki perusahaan bukan satu-satunya pertimbangan auditor dalam memberikan opini audit going concern. Masih banyak rasio lain yang menjadi faktor penilai kondisi ekonomi perusahaan seperti rasio aktivitas, likuiditas, rentabilitas dan solvabilitas. Sedangkan pertumbuhan perusahaan yang ditunjukkan dengan rasio penjualan perusahaan tidak dapat menjamin perusahaan mengalami peningkatan laba.

\section{Saran}

Untuk peneliti berikutnya disarankan menambah periode penelitian sehingga dapat memperoleh sampel yang lebih besar. Selain itu juga menambah variabel selain prediksi kebangkrutan, leverage dan pertumbuhan perusahaan dalam mengkaji pemberian opini audit going concern.

\section{DAFTAR RUJUKAN}

Auditing Standar Board. 1998. Statement on Standar Standards. New York: AICPA.

Altman, E.I. 1968. Financial ratios Discriminant Analysis and The Prediction of Corporate Banckrupcy. Journal of Finance.

Altman, E., \& T. McGouh. 1974. Evaluation of A Company as A Going Concern, Journal of Accountancy. Auditing Journal Practice and Theory Fall.

Chen, K.C., \& B.K. Church. 1992. Default on Debt Obligations and the Issuance of Going Concern Report, A Journal of Practice \&Theory. Fall. 30-49.

Fanny, M., dan Saputra, S. 2005. Opini Audit Going Concern: Kajian Berdasarkan model Prediksi Kebangkrutan, Pertumbuhan Perusahaan dan Reputasi Kantor Akuntan Publik, Simpusium Nasional Akuntansi VIII.

IAPI. 2001. Standar Proffesional Akuntan Publik per 1 Januari. Jakarta: Salemba Empat. IAI. 2001. Standat Profesional Akuntan Publik (SPAP). Jakarta: Salemba Empat. 
Imam Ghozali. 2008. Aplikasi Multivariate dengan program SPSS, Badan Penerbit Universitas Diponegoro.

Lenard, M.J., Perualz, A., dan David, B. 1998. An Analysis of Fuzzy Clustering and a Hybrid Model for Auditor' Going Concern.

Mc Keown, J.C. Towards an Explanation of Auditor failure to Modify the Audit Opinion of Bankrupt Companies, Auditing: A Journal of Practice and Theory.

Mutchler, J.F. Auditor's Perception of The Going Concern Opinion Decision, Journal of Accounting Research, Autumn.

Petronela, T. 2004. Pertimbangan Going concern Perusahaan dalam Pemberian Opini Audit, Jurnal Balance.

Rahayu, A.W., dan Pratiwi, C.W. 2011. Pengaruh Opini Audit Tahun Sebelumnya, Pertumbuhan perusahaan, Leverage, dan Reputasi Auditor terhadap Penerimaan opini Audit Going Concern, Proceeding PESAT Univiversitas Gunadarma.

Rahman, A., dan Baldric, S. 2011, Faktor-Faktor yang mempengaruhi Kecenderungan Penerimaan opini Audit Going Concern pada Perusahaan Manufaktur yang terdapat di BEI, penelitian belum dipublikasikan.

Rudyawan, A.P. 2007. Opini Audit Going Concern: Kajian Berdasarkan Model Prediksi Kebangkrutan, Pertumbuhan Perusahaan dan Reputasi Kantor Akuntan Publik.

Uyanto, S. 2006. Pedoman Analisis Data dengan SPSS. Yogjakarta: Graha Ilmu.

Warnida. 2011. Analisis Faktor-Faktor yang Mempengaruhi Penerimaan Opini Audit Going Concern, Jurnal Akuntansi \& Manajemen, Vol 6, No. 1, Hal 30-43. 